Johnson, Nicholas K.; Zumhof, Tim

\title{
"Are you not entertained?". Education, entertainment, and historical representations on stage and screen in Germany and the USA, an introduction
}

Zumhof, Tim [Hrsg.]; Johnson, Nicholas K. [Hrsg.]: Show, don't tell. Education and historical representations on stage and screen in Germany and the USA. Bad Heilbrunn : Verlag Julius Klinkhardt 2020, S. 7-14. - (Studien zur Deutsch-Amerikanischen Bildungsgeschichte / Studies in German-American Educational History)

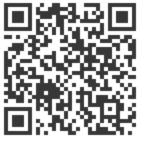

Quellenangabe/ Reference:

Johnson, Nicholas K.; Zumhof, Tim: "Are you not entertained?". Education, entertainment, and historical representations on stage and screen in Germany and the USA, an introduction - In: Zumhof, Tim [Hrsg.]; Johnson, Nicholas K. [Hrsg.]: Show, don't tell. Education and historical representations on stage and screen in Germany and the USA. Bad Heilbrunn : Verlag Julius Klinkhardt 2020, S. 7-14 - URN: urn:nbn:de:0111-pedocs-205075 - DOI: 10.25656/01:20507

https://nbn-resolving.org/urn:nbn:de:0111-pedocs-205075

https://doi.org/10.25656/01:20507

in Kooperation mit / in cooperation with:

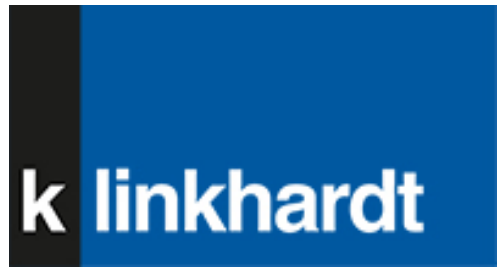

http://www.klinkhardt.de

\section{Nutzungsbedingungen}

Dieses Dokument steht unter folgender Creative Commons-Lizenz: http://creativecommons.org/licenses/by-nc-sa/4.0/deed.de - Sie dürfen das Werk bzw. den Inhalt unter folgenden Bedingungen vervielfältigen, verbreiten und öffentlich zugänglich machen sowie Abwandlungen und Bearbeitungen des Werkes bzw. Inhaltes anfertigen: Sie müssen den Namen des Autors/Rechteinhabers in der von ihm festgelegten Weise nennen. Dieses Werk bzw. der Inhalt darf nicht für kommerzielle Žwecke verwendet werden. Die neu entstandenen Werke bzw. Inhalte dürfen nur unter Verwendung von Lizenzbedingungen weitergegeben werden, die mit denen dieses Lizenzvertrages identisch oder vergleichbar sind.

Mit der Verwendung dieses Dokuments erkennen Sie die Nutzungsbedingungen an.

\section{Terms of use}

This document is published under following Creative Commons-License: http://creativecommons.org/licenses/by-nc-sa/4.0/deed.en - You may copy, distribute and transmit, adapt or exhibit the work in the public and alter, transform or change this work as long as you attribute the work in the manner specified by the author or licensor. You are not allowed to make commercial use of the work. If you alter, transform, or change this work in any way, you may distribute the resulting work only under this or a comparable license.

By using this particular document, you accept the above-stated conditions of use.

\section{Kontakt / Contact:}

\section{peDOCs}

DIPF | Leibniz-Institut für Bildungsforschung und Bildungsinformation Informationszentrum (IZ) Bildung

E-Mail: pedocs@dipf.de

Internet: www.pedocs.de

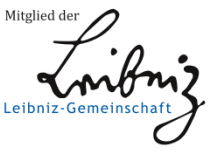




\section{Studien zur Deutsch-Amerikanischen}

Bildungsgeschichte / Studies in German-American Educational History

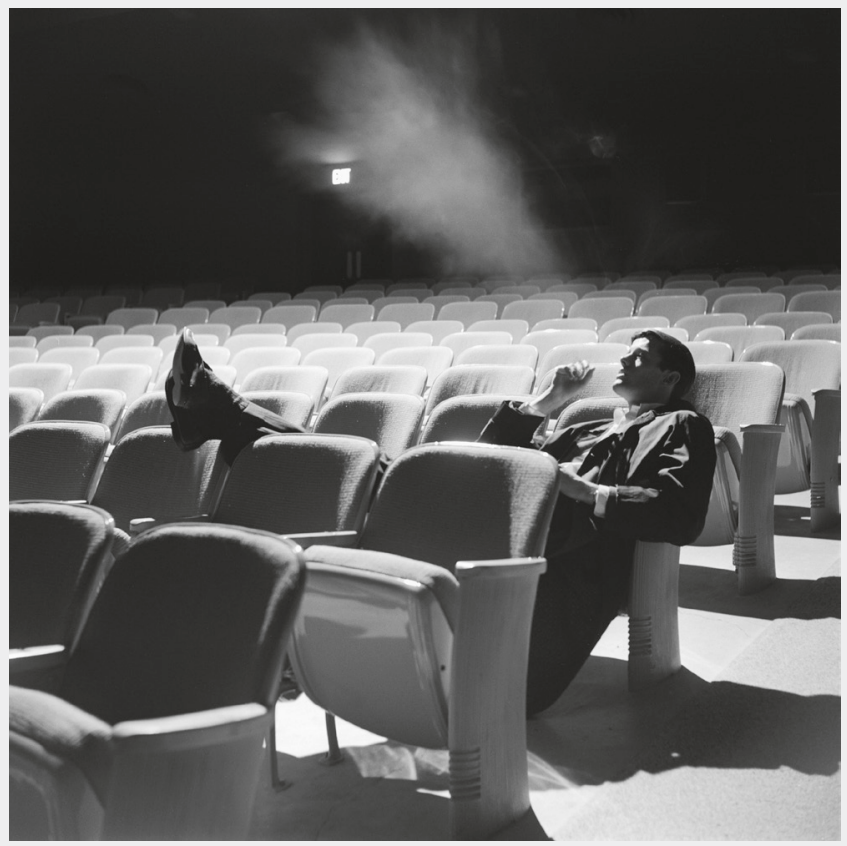

Tim Zumhof

Nicholas K. Johnson (eds.)

Show, Don't Tell

Education and Historical Representations on Stage and Screen in Germany and the USA 


\section{Zumhof / Johnson Show, Don't Tell}


Studien zur Deutsch-Amerikanischen Bildungsgeschichte Studies in German-American Educational History

General Editor Jürgen Overhoff 


\section{Tim Zumhof \\ Nicholas K. Johnson (eds.)}

\section{Show, Don't Tell}

Education and Historical Representations on Stage and Screen in Germany and the USA 
This volume was published in cooperation with the Center for German-American Educational History at the University of Münster.

Titel entstand in Kooperation mit der „Arbeitsstelle für Deutsch-Amerikanische Bildungsgeschichte".

\section{Arbeitsstelle für Deutsch-Amerikanische Bildungsgeschichte}

Dieser Titel wurde in das Programm des Verlages mittels eines Peer-Review-Verfahrens aufgenommen. Für weitere Informationen siehe www.klinkhardt.de.

Bibliografische Information der Deutschen Nationalbibliothek

Die Deutsche Nationalbibliothek verzeichnet diese Publikation in der Deutschen Nationalbibliografie; detaillierte bibliografische Daten sind im Internet abrufbar über http://dnb.d-nb.de.

2020.lg. (C) by Julius Klinkhardt.

Bildnachweis Umschlagseite 1: (C) Francis Miller (1961). Peter Fonda in theater audience seats at Omaha Nebraska Community Playhouse. The LIFE Picture Collection via Getty Images. - The cover photo is used for illustrative purposes only and does not represent an endorsement by the Peter Fonda estate.

Druck und Bindung: AZ Druck und Datentechnik, Kempten.

Printed in Germany 2020.

Gedruckt auf chlorfrei gebleichtem alterungsbeständigem Papier.

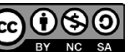

Die Publikation (mit Ausnahme aller Fotos, Grafiken und Abbildungen) ist veröffent-

licht unter der Creative Commons-Lizenz: CC BY-NC-SA 4.0 International

https://creativecommons.org/licenses/by-nc-sa/4.0/

ISBN 978-3-7815-5828-1 Digital

doi.org/10.35468/5828

ISBN 978-3-7815-2397-5 Print 


\section{Table of Contents}

Nicholas K. Johnson and Tim Zumhof

"Are you not entertained?" -

Education, Entertainment, and Historical Representations

on Stage and Screen in Germany and the USA, an Introduction .7

Tim Zumbof

Historical Culture, Public History, and Education

in Germany and the United States of America.

A Comparative Introduction to Basic Concepts and Fields of Research.

Jürgen Overhoff

"Geschichte ist etwas Fließendes."

Lion Feuchtwanger's Changing Understanding of History

and the Role of the Stage: From his Earliest Theatrical Productions

to his Play Waffen für Amerika (1943/44)

Simon Richter

Duell an der Havel:

Fritz von Unruh's Depiction of Eighteenth-Century

Prussian-American Relations

Alissa Rubinstein

The 614th Commandment:

A Documentary Play about how American Jews Feel

about Germany Today

Wolfgang Hochbruck

Living History as an Educational Tool and Method

in North America and Germany

Stephanie Johns

Theatre, Education, and Public History:

Teaching History at the Stratford Festival 
6 Table of Contents

Felix Apel

Hollywood's Influence on the Transmission of Historical Images:

Lars Kraumes' Der Staat gegen Fritz Bauer

Thorsten Carstensen

Learning from John Ford:

History, Geography, and Epic Storytelling in the Works of Peter Handke

Raymond Haberski, Jr.

The Passion of Richard Schickel: What We Expect from War Films

160

Nicholas K. Johnson

"A classroom history lesson is not going to work":

HBO's Conspiracy and Depicting Holocaust Perpetrators on Film

Table of Figures

List of Contributors

Index

Acknowledgements 


\section{Nicholas K. Johnson and Tim Zumhof}

\section{"Are you not entertained?" - \\ Education, Entertainment, and Historical \\ Representations on Stage and Screen in Germany \\ and the USA, an Introduction}

In 2000, Ridley Scott revived the presumed dead swords-and-sandal movie genre with his Oscar-winning movie Gladiator. In this film, the Roman general Maximus, played by Russell Crowe, is to succeed the dying emperor Marcus Aurelius, (Richard Harris). But his son Commodus, played by Joaquin Phoenix, wants to prevent this. He kills his father and orders the execution of Maximus and his family. Maximus manages to escape and is captured by slave traders. Thereafter, he must fight as a gladiator. In the end, he arrives at the Coliseum and takes revenge on Commodus.

The movie is probably less inspired by ancient history than by film history. It is "reel history" rather than "real history." Commodus' death at the end of the movie is inspired by Anthony Mann's The Fall of the Roman Empire (1964), starring Christopher Plummer as Commodus. Scott confessed that epic movies from the 1950s and 1960s like Ben Hur (1959) or Stanley Kubrick's Spartacus (1960) heavily influenced his visuals. David Franzoni, the screenwriter of Gladiator, even noted that the film itself was partly about modern anxieties over the power of popular entertainment. ${ }^{1}$ He noted that " $\left.\mathrm{t}\right]$ he movie is about us. It's not just about ancient Rome, it's about America."2 Maybe that explains why Harvard historian Kathleen M. Coleman, who worked as a historical advisor for the film, refrained from being named as such in the end credits. Although she confessed that the film increased students' interest in ancient history, she criticized it because it was not concerned with historical authenticity and did not follow the latest findings of historical research. Instead, it perpetuated a long-outdated image of antiquity originating in the nineteenth century like Jean-Léon Gérôme's painting Police verso (1872) or in Lawrence Alma-Tadema's artistic renderings of Roman luxury and decadence. "Is it proper to let the cinema-going public think that the past looked like our cinematic conception of it?" Coleman asked. "Will generations to come persist in believing that the cinematic fiction is what 'really happened'? If so - and this is the really

1 Monica S. Cyrino. "Gladiator and Contemporary American Society," in Gladiator. Film and History, ed. by Martin M. Winkler (Oxford: Blackwell Publishing, 2004), 125-149. 138.

2 Cyrino, "Gladiator and Contemporary American Society," 125. 
worrying question, especially on the lips of those whose bank balances are swelled by the takings at the box office - does it matter?" 3 In other words: "Are you not entertained? Is this not why you are here?"

In 2018, the Center for German-American Educational History (Arbeitsstelle für Deutsch-Amerikanische Bildungsgeschichte) at the University of Münster organized a lecture series in which educators, historians, and researchers discussed the question of just what audiences "learn" from historical representations on screen and stage, if movies, plays, and TV shows form, influence, and shape historical consciousness and how theater, television, and cinema can "teach" history and historical thinking. These questions aim at the complicated relationship between entertainment and education, excitement and enlightenment surrounding historical representation in popular media. Screen and stage plays use history to tell thrilling and insightful stories, to reflect on the human condition and - if nothing else - to sell entertainment. These productions are no documentaries, but dramatic representations of historical events, persons and circumstances.

With the title "Show, Don't Tell," we emphasize on the one hand the special condition of these dramatic representations of history compared to their written counterparts, such as historical novels. On the other hand, we allude to the educational dimension of "showing" in general. The German philosopher of education Klaus Prange claims that demonstrating, representing, or showing something to someone is at the heart of any educational action. ${ }^{4}$ Although not every act of representing or showing must be considered an educational action, the question stands whether historical representations on screen and stage have an educational dimension to consider. Even so, movies, TV shows, and other dramatic representations of history contribute to our historical consciousnesses and our cultural identities, which are not irrelevant for understanding education in societies. Therefore, the contributions in this volume illustrate and analyze historical representations in popular dramatic media as a part of the historical cultures of Germany and the USA and show how theater and moviemakers use history to engage audiences in memory culture, influence historical consciousness, and connect present issues and prospects of the future with their interpretations of historic events, characters, and circumstances. In the first contribution Tim Zumhof, researcher at the Institute for Educational Research at the University of Münster, presents various theoretical and practical approaches from the US and Germany that tackle the question of how people and societies deal with their histories. He identifies similarities and differences between concepts like public history, popular history, and historical culture and asks

3 Kathleen M. Coleman. "The Pedant goes to Hollywood: The Role of the Academic Consultant," in Gladiator. Film and History, ed. by Martin M. Winkler (Oxford: Blackwell Publishing, 2005), 45-52. 50.

4 Klaus Prange. "Über das Zeigen als operative Basis der pädagogischen Kompetenz," Bildung und Erziehung 48.2 (1995): 145-158. 
whether they reflect on the educational dimension of historical representations in popular media. He also addresses research desiderata, hints at possibilities of interdisciplinary research, and describes the history of historical cultures as a neglected subject for the History of Education field.

Although German academics long-ignored popular culture, there has been a longstanding German tradition which considers theater an educational and moral institution. From Friedrich Schiller to Bertolt Brecht, theater reformers thought about theater as an important aid for educating people about the human condition, social change, and other pressing issues by using historical settings. However, German author Lion Feuchtwanger, who is famous for his historical novels and plays, was very skeptical of Brecht's educational efforts through his Epic Theater concept. Nevertheless, in his essay, Jürgen Overhoff, Professor for History of Education at the University of Münster, shows how Feuchtwanger's attitude towards educational aspirations changed through his experience with the rise of fascism in Germany. Feuchtwanger's play Waffen für Amerika (1946), which he wrote after he fled from Nazi Germany to the USA, deals with the Franco-American military alliance of 1778 against the British in the War of Independence. At the same time, he implies certain parallels to current events. For Feuchtwanger, the forging of a military alliance of Britain, the USA, and the Soviet Union against Nazi Germany was a callback to this earlier European-American cooperation in transatlantic history. The lesson Feuchtwanger wants his audience to learn from this history is to find confidence in the human progress achieved through the European-American alliance and that despite all chauvinistic abuses, both sides of the Atlantic will in the end prevail.

Since the earliest days of theater, playwrights have drawn ideas and inspiration from history. The most famous example is, of course, William Shakespeare. At the beginning of his career, he wrote eleven plays about English history thanks to the availability of serious historical works like Edward Hall's The Union of the Two Noble and Illustre Families of Lancaster and York (1548) and Raphael Holinshed's Chronicles of England, Scotland and Ireland (1577/1587). However, the British popular historian Dan Jones reminds us: "What we should always remember is that Shakespeare wrote plays primarily to entertain - his plays were never supposed to comprise a history lesson, but simply drew an audience by virtue of its historical setting." ${ }^{5} \mathrm{He}$ often used history as an allegory to comment on events of his own time, he was biased in his descriptions and characterizations of historical figures, and wrote his plays in the historical boundaries of specific dramatic traditions and under specific social conditions.

5 Dan Jones. "Shakespeare: did he get his history right?" 2013, The Daily Telegraph, URL: https:// www.telegraph.co.uk/culture/theatre/william-shakespeare/10106855/Shakespeare-did-he-get-hishistory-right.html (accessed November 12, 2019). 
In his play Duell an der Havel (1954), the German playwright Fritz von Unruh even took the liberty to imagine a fictional encounter between historic figures like Frederick the Great of Prussia and President George Washington. In his play, Unruh attempts a difficult mediation between opposing models of Enlightenment governance and the opposition of freedom and duty. Although historic events in Unruh's play are completely invented and staged, Simon Richter, Professor for Germanic Languages and Literatures at the University of Pennsylvania, argues that the play holds up as a way of thinking about the complex history of the transatlantic relationship between Germany and the United States, from Washington and Fredrick the Great to Trump and Merkel.

Even if screenwriters and playwrights consider Mark Twain's remarks on writing fiction - to get your facts first, and then distort them as much as you please $-{ }^{6}{ }^{6}$ it is no guarantee of any historical authenticity. Historical representations on stage and screen can nevertheless create an "authentic atmosphere" which depends on visual details like costumes, artifacts, and architecture. It depends upon the ideology and behavior of characters and a plot that fits into a historical context. Nevertheless, "historical authenticity" is certainly not the main goal of dramatists, in contrast to creating a historical documentary. Historical authenticity in popular media has to be harmonized with aesthetic and dramatic considerations. ${ }^{9}$ With concepts like documentary theater (Dokumentartheater), theater-makers challenge historical authenticity and try to make historical sources accessible on stage. Since 2007, students of the Institute of History at the University of Bremen, Germany, and actors from the Bremen Shakespeare company (bsc) have developed and staged dramatic readings of historical documents under the title Staging Files. The German historian Eva Schönk-Quinteros developed the concept for this unique project which combines historical and dramaturgical work. Its aim is to make files and historical documents "speak" on stage, to make source-based research accessible to a broad public, and to address current political issues. The dramatic reading is ideal for these purposes because it relies heavily on the language of the documents and allows presenting historical texts without additional explanations, comments or interpretations. ${ }^{10}$ In 2016, Alissa Rubinstein, a public historian and playwright working in Berlin, created another unique theater project based on collected sources. Her play The $614^{\text {th }}$ Commandment is a result of over two years of research on the intersections of public history, documentary theater, and Jewish collective memory undertaken

6 See Rudyard Kipling. From Sea to Sea: Letters of Travel. Vol. 2. (London: Doubleday \& McClure Company 1899), 180.

7 Coleman, "The Pedant goes to Hollywood," 47.

8 Coleman, "The Pedant goes to Hollywood," 47.

9 Coleman, "The Pedant goes to Hollywood," 48.

10 Sigrid Dauks. 'Aus den Akten auf die Bühne': Inszenierungen in der archivischen Bildungsarbeit (Berlin: BibSpider, 2010). 
as part of Rubinstein's Master's thesis research for her Public History degree at the Free University of Berlin. The play itself is based on over 200 interviews conducted with American Jews in Los Angeles, California. Rubinstein was inspired to embark on this project because of her both her own family history as well as her own experiences living in Berlin. Both the essay and the play deal with the intergenerational passing down of historical trauma and memory and ask how - or if - remembering such painful history can ever become less painful.

In addition to documentary theater, performances that reenact historical events with amateur actors prove to be a form of historical theater that keeps memories alive. Therefore, Jens Roselt and Ulf Otto recently described theater as a "time machine" in their anthology of the same name. ${ }^{11}$ Looking at the historical re-enactments at the Offenburger Freedom Festival ${ }^{12}$ in Germany or Colonial Williamsburg, Virginia, Wolfgang Hochbruck, Professor for North American Studies at the University of Freiburg, draws attention to the entangled German-American history of the Civil War and discusses the limits and possibilities offered by historical reenactments for history and civic education. He argues that besides the accepted forms of experimental archeology and living history programs in openair museums, historical theater - with students both as actors and audiences in live-action roleplay - can create positive effects for school curriculum-based learning processes.

Even commercial theaters now offer a variety of educational programs for their historical theater productions which provide historical backgrounds and contexts for the plays and enrich regular theater experiences with aspects of historical learning. Stephanie Johns, educator at Canada's largest theater festival - the Stratford Festival -, presents a variety of techniques for teaching complicated histories in conjunction with the current playbill. For example, for the stage play adaptations of The Diary of Anne Frank or Harper Lee's To Kill A Mockingbird, the Stratford Festival arranged post-show chats, workshops, and prologues. In her contribution, Johns talks about her experiences with this educational framework program and reflects on the impact it had on the audiences.

The second half of our volume turns to depictions of history in film and television. Since the beginning of film history, filmmakers have portrayed history on screen and generated (or reinforced) historical images. One notable example is D.W. Griffith's infamous Birth of a Nation (1915), which perpetuates racist Lost Cause myths and promotes the Ku Klux Klan. Film historian Bruno Ramirez argued that then-president Woodrow Wilson's praise of the film "could also be taken as an in-

11 See Jens Roselt and Ulf Otto ed., Theater als Zeitmaschine. Zur performativen Praxis des Reenactments. Theater- und kulturwissenschaftliche Perspektiven (Bielefeld: transcript, 2012).

12 Stadt Offenburg. "Offenburger Freiheitsfest," URL: https://www.offenburg.de/html/content/ offenburger_freiheitsfest.html (accessed November 12, 2019). 
formal validation of the new medium's power to 'write history."'13 Since the 1990s, academics have increasingly analyzed films in their own right from the perspectives of history, aesthetics, education, and memory studies. In their groundbreaking study The Presence of the Past (1998), Roy Rosenzweig and David Thelen note that film and television are the most common way Americans encounter history. ${ }^{14}$ Robert Rosenstone, a film historian and strong advocate for the medium's potential, has argued that other historians should learn to "read" film and that "[f]ilms seem simple because on a surface level they are so easy to watch." ${ }^{15}$ For him, films "expand the vocabulary with which we think and write history upon the page."16 Other scholars such as Alison Landsberg, have argued that modern mass culture implants "prosthetic memories" of historical events in diverse and diffuse audiences; the advantage of this phenomenon is that it can help foster historical empathy for "foreign" historical actors or minority groups. ${ }^{17}$ Three of our contributions analyze films that depict the Second World War and the Holocaust. In line with earlier work on "prosthetic memory" and "cosmopolitan memory," these pieces trace how films create historical images and influence historical memory for global audiences widely removed from the original events' national contexts. ${ }^{18}$ This is not to say that films are infallible or are have surpassed traditional written history - one only needs to look at the previous example of Gladiator to be disabused of that notion but nevertheless, historical films and television series are here to stay.

FeLIX Apel begins the remainder of this volume by discussing the concept of historical images and how storytelling conventions pioneered in early twentieth-century Hollywood became global practices. His contribution uses the film Der Staat gegen Fritz Bauer (2015) as a case study for the creation and transmission of historical images on film. The film, a dramatization of Fritz Bauer's involvement with the capture of Adolf Eichmann, explores the Attorney General's life before he served as lead prosecutor at the Frankfurt Auschwitz Trials (1963-1965). Apel analyzes the ways that Der Staat gegen Fritz Bauer utilizes storytelling techniques pioneered in Hollywood to construct historical images of the Hessian Attorney General while simultaneously perpetuating well-worn myths about Bauer's private life. For Apel, the film exemplifies our current globalized film culture, where differences in na-

13 Bruno Ramirez. Inside the Historical Film (Montreal: McGill-Queen's University Press, 2014), 21.

14 Roy Rosenzweig and David Paul Thelen. The Presence of the Past: Popular Uses of History in American Life (New York: Columbia University Press, 1998), 31.

15 Robert A. Rosenstone. "The Reel Joan of Arc: Reflections on the Theory and Practice of the Historical Film." The Public Historian 25.3 (2003): 61-77. 70.

16 Rosenstone, "The Reel Joan of Arc," 77.

17 See Alison Landsberg. Prosthetic Memory: The Transformation of American Remembrance in the Age of Mass Culture (New York: Columbia University Press, 2004), and Engaging the Past: Mass Culture and the Production of Historical Knowledge (New York: Columbia University Press, 2015).

18 See Daniel Levy and Natan Sznaider. "Memory Unbound: The Holocaust and the Formation of Cosmopolitan Memory." European Journal of Social Theory 5.1 (2002): 87-106. 
tional filmmaking styles have largely fallen by the wayside in favor of films that appeal to more global, transnational audiences connected to streaming services and no longer dependent on the theatrical distribution model.

Historical images originally meant for one national audience can nevertheless influence audiences worldwide. In his contribution, Thorsten Carstensen, Associate Professor of German at Indiana University-Purdue University Indianapolis (IUPUI), analyzes the transatlantic transfer of historical images at the microlevel. His contribution explores how John Ford's depiction of the American West profoundly influenced Austrian writer Peter Handke, winner of the 2019 Nobel Prize in Literature. Handke's work is full of direct and indirect references to John Ford's life and work. Ford was a pioneer of the Western genre and greatly contributed to cementing the West as the American epic myth. Handke's ideas about America and the West, as well as many aspects of his artistic life, can be directly traced to the cinema of John Ford, which is characterized by everyday people, the epic landscapes of Monument Valley, and the bonds that hold communities together. For Handke, John Ford served as his teacher; watching Ford's films was an educational experience about both American history and life itself. Ford's depictions of the American West imbued Handke with a "prosthetic memory" of the American West without having experienced it firsthand. ${ }^{19}$ By examining John Ford's reception at the microlevel, Carstensen illustrates the power historical images can have over diverse audiences.

Most work on historical films ignores the role of critics. RaYmond J. HabersKi, Professor of American Studies and History at IUPUI, continues Carstensen's focus on the reception of historical films but shifts it towards film critics and historical memory. This article examines the film historian and critic Richard Schickel's negative reception of Hollywood war films, particularly William Wyler's The Best Years of Our Lives (1946). For Haberski, critics like Richard Schickel miss the mark when they deride war films such as The Best Years of Our Lives as jingoistic and unrealistic lies because they expect too much from the Hollywood dream factory and fall into the trap of casting themselves as crusaders for truth against patriotic propaganda. Haberski argues for a more nuanced approach towards war films which treats audiences with respect instead of as passive consumers unwittingly accepting every fiction Hollywood delivers them. This contribution argues for an acknowledgment of the historical context in which films like The Best Years of Our Lives were made and a more balanced approach for analyzing Hollywood's depiction of World War II. The final contribution examines the production history of Conspiracy (2001), a dramatization of the 1942 Wannsee Conference. In his piece, Nicholas K. Johnson, Deputy Head of the Research Center for German-American Educational

19 See Alison Landsberg. Prosthetic Memory: The Transformation of American Remembrance in the Age of Mass Culture (New York: Columbia University Press, 2004). 
History at the University of Münster, uses archival sources such as script drafts, meeting minutes, and correspondence in order to trace just how filmmakers create historical images. This piece critically assesses Conspiracy as a case study for how filmmakers responsibly make complex and difficult histories accessible to wide audiences while largely avoiding cliché and sentimentality. Furthermore, as an Anglo-American production, Conspiracy also serves as an example of how Americans have depicted a key event from "German" history that had global impact.

In summary, all of the contributions to this volume explore the depiction of history in theater and film from the intersection of historical scholarship, aesthetics, memory studies, and education. They examine the creation of historical images, film production and reception, the scriptwriting process, educational programming, and depictions of German-American encounters. Above all else, they explore how various theatrical and filmic productions show history rather than tell it.

\section{Cited Works}

Coleman, Kathleen M. "The Pedant goes to Hollywood: The Role of the Academic Consultant," in Gladiator. Film and History, ed. by Martin M. Winkler (Oxford: Blackwell Publishing, 2005), 45-52.

Cyrino, Monica S. "Gladiator and Contemporary American Society," in Gladiator. Film and History, ed. by Martin M. Winkler (Oxford: Blackwell Publishing, 2004), 125-149.

Dauks, Sigrid. 'Aus den Akten auf die Bühne': Inszenierungen in der archivischen Bildungsarbeit. Berlin: BibSpider, 2010.

Jones, Dan. “Shakespeare: did he get his history right?" The Daily Telegraph, 2013, URL: https://www. telegraph.co.uk/culture/theatre/william-shakespeare/10106855/Shakespeare-did-he-get-his-history-right.html (accessed November 12, 2019).

Kipling, Rudyard. From Sea to Sea: Letters of Travel. Vol. 2. London: Doubleday \& McClure Company, 1899.

Landsberg, Alison. Engaging the Past: Mass Culture and the Production of Historical Knowledge. New York: Columbia University Press, 2015.

Landsberg, Alison. Prosthetic Memory: The Transformation of American Remembrance in the Age of Mass Culture. New York: Columbia University Press, 2004.

Levy, Daniel and Natan Sznaider. "Memory Unbound: The Holocaust and the Formation of Cosmopolitan Memory." European Journal of Social Theory 5.1 (2002): 87-106.

Prange, Klaus. "Über das Zeigen als operative Basis der pädagogischen Kompetenz." Bildung und Erziehung 48.2 (1995): 145-158.

Ramirez, Bruno. Inside the Historical Film. Montreal: McGill-Queen's University Press, 2014.

Roselt, Jens and Ulf Otto (ed.). Theater als Zeitmaschine. Zur performativen Praxis des Reenactments. Theater-und kulturwissenschaftliche Perspektiven (Bielefeld: transcript, 2012).

Rosenstone, Robert A. "The Reel Joan of Arc: Reflections on the Theory and Practice of the Historical Film.” The Public Historian 25.3 (2003): 61-77.

Rosenzweig, Roy and David Paul Thelen. The Presence of the Past: Popular Uses of History in American Life. New York: Columbia University Press, 1998.

Stadt Offenburg. "Offenburger Freiheitsfest,“ URL: https://www.offenburg.de/html/content/offenburger_freiheitsfest.html (accessed: November 12, 2019). 